\title{
A Physical Therapist and Physical Therapist Assistant Learning Activity to Examine Student Collaboration and Collaboration Readiness: An Intraprofessional Educational Process
}

\author{
Salome V. Brooks \\ Springfield College - Springfield, MA, salome.brooks@gordon.edu \\ Renae Gorman \\ Springfield Technical Community College, Springfield MA, rgorman@stcc.edu
}

Follow this and additional works at: https://nsuworks.nova.edu/ijahsp

Part of the Medicine and Health Sciences Commons, and the Scholarship of Teaching and Learning Commons

This Manuscript has supplementary content. View the full record on NSUWorks here: https://nsuworks.nova.edu/ijahsp/vol15/iss1/9

\section{Recommended Citation}

Brooks SV, Gorman R. A Physical Therapist and Physical Therapist Assistant Learning Activity to Examine Student Collaboration and Collaboration Readiness: An Intraprofessional Educational Process. The Internet Journal of Allied Health Sciences and Practice. 2017 Jan 01;15(1), Article 9.

This Manuscript is brought to you for free and open access by the College of Health Care Sciences at NSUWorks. It has been accepted for inclusion in Internet Journal of Allied Health Sciences and Practice by an authorized editor of NSUWorks. For more information, please contact nsuworks@nova.edu. 


\title{
A Physical Therapist and Physical Therapist Assistant Learning Activity to Examine Student Collaboration and Collaboration Readiness: An Intraprofessional Educational Process
}

\begin{abstract}
BACKGROUND: Workforce responsibilities in the clinical setting between the physical therapist (PT) and physical therapist assistant (PTA) emphasize the necessity to develop intraprofessional skills fostering discipline collaboration. These skills impact the team process and the achievement of interprofessional patient centered outcomes. Collaboration is a skill that is sought after in inter- and intraprofessional teams. Intraprofessionalism is occurring within teamwork and collaborative activities labelled or described in interprofessional terms and tools. Health science professional programs have received recent mandates to address interprofessional collaboration skills within curricula. But disciplines that contain multiple professional roles need to address the within discipline, prerequisite intraprofessional skills prior to the field being represented in the care setting. PURPOSE: The purpose of this study is to examine PT and PTA student readiness to learn team collaboration skills within an academic setting and reveal the characteristics of intraprofessional education through the completion of a "professionalism" classroom focused project. METHODS: Following an explanatory sequential mixed methods approach, 54 PT and PTA students completed pre/post the Readiness for Interprofessional Learning Scale (RIPLS) and Interdisciplinary Education Perception Scale (IEPS). Qualitative data collected included student previous supervisory work experiences, independent student meeting process descriptors, and student performance self/peer evaluations. RESULTS: The results showed that the overall RIPLS score increase pre to post was influenced by the strong values within the subscale "Teamwork and Collaboration" expressing the student perspective. IEPS subscales scores indicated consistently a student value for collaboration. The independent student meeting process was conducted without PT/PTA degree level distinctions and task accomplishment appeared seamless. Peer evaluations revealed the existence of collaboration characteristics within groups and individual student qualities. CONCLUSIONS: The results from the interprofessional tools used in this study support the inclusion of intraprofessional collaboration skills development in the classroom. Intraprofessional skills can be fostered in the academic setting as promoted by interprofessional education (IPE) mandates prerequisite to entering the clinic.
\end{abstract}

\section{Author Bio(s)}

Salome V. Brooks PT EdD MBA MA is an Assistant Professor in the Physical Therapy Program, School of Health Sciences and Rehabilitation Studies, Springfield College, Springfield MA. She is responsible for teaching the professional practice/management thread, research writing and applied research courses.

Renae Gorman PT DPT OCS is an Assistant Professor and Director of Clinical Education in the Physical Therapist Assistant Program at Springfield Technical Community College, Springfield MA. She is responsible for teaching applied practice and research analysis courses in addition to clinical placements.

\section{Acknowledgements}

We would like to thank Michael Ward PhD, College of Liberal Arts and Sciences at the University of lowa, for his assistance with the SPSS program and for his quantitatively focused comments during the course of this research that greatly improved the manuscript. 


\title{
1JAHSP \\ The Internet Joưnal of Allied Health Sciences and Practice
}

Dedicated to allied health professional practice and education

Vol. 15 No. 1 ISSN 1540-580X

\section{A Physical Therapist and Physical Therapist Assistant Learning Activity to Examine Student Collaboration and Collaboration Readiness: An Intraprofessional Educational Process}

\author{
Salome V. Brooks, PT, EdD, MBA, MA 1 \\ Renae Gorman, PT, DPT, OCS ${ }^{2}$
}

1. Springfield College - Springfield, MA

2. Springfield Technical Community College, Springfield MA

\section{United States}

\begin{abstract}
BACKGROUND: Workforce responsibilities in the clinical setting between the physical therapist (PT) and physical therapist assistant (PTA) emphasize the necessity to develop intraprofessional skills fostering discipline collaboration. These skills impact the team process and the achievement of interprofessional patient centered outcomes. Collaboration is a skill that is sought after in inter- and intraprofessional teams. Intraprofessionalism is occurring within teamwork and collaborative activities labelled or described in interprofessional terms and tools. Health science professional programs have received recent mandates to address interprofessional collaboration skills within curricula. But disciplines that contain multiple professional roles need to address the within discipline, prerequisite intraprofessional skills prior to the field being represented in the care setting. PURPOSE: The purpose of this study is to examine PT and PTA student readiness to learn team collaboration skills within an academic setting and reveal the characteristics of intraprofessional education through the completion of a "professionalism" classroom focused project. METHODS: Following an explanatory sequential mixed methods approach, 54 PT and PTA students completed pre/post the Readiness for Interprofessional Learning Scale (RIPLS) and Interdisciplinary Education Perception Scale (IEPS). Qualitative data collected included student previous supervisory work experiences, independent student meeting process descriptors, and student performance self/peer evaluations. RESULTS: The results showed that the overall RIPLS score increase pre to post was influenced by the strong values within the subscale "Teamwork and Collaboration" expressing the student perspective. IEPS subscales scores indicated consistently a student value for collaboration. The independent student meeting process was conducted without PT/PTA degree level distinctions and task accomplishment appeared seamless. Peer evaluations revealed the existence of collaboration characteristics within groups and individual student qualities. CONCLUSIONS: The results from the interprofessional tools used in this study support the inclusion of intraprofessional collaboration skills development in the classroom. Intraprofessional skills can be fostered in the academic setting as promoted by interprofessional education (IPE) mandates prerequisite to entering the clinic.
\end{abstract}

\section{INTRODUCTION}

In recent years, health science professional programs have been cultivating the inclusion of collaborative skills in their core curriculum. Collaboration skills and the ability to appreciate working colleagues are capabilities that can be introduced and practiced in the academic course of study for the healthcare student. As a general trend, physical therapy (PT) and physical therapist assistant (PTA) students interact minimally during their professional education. Traditionally, interaction between the PT and PTA student rarely occurs in the clinical experience. Confusion about the role of the PTA in collaboration with PT practice is often the result of a lack of early opportunities. The reason for the limited opportunity of a shared educational event is unknown. ${ }^{1}$ Yet, the post-graduate expectations in the workplace demands these two members of the health care workforce understand each other, collaborate in patient care, coordinate administrative functions, and ultimately work as a team.1,2 According to Plack et al, by 2020 , the PT to PTA team ratio may expand in the workforce potentially exceeding a $3: 5$ ratio. ${ }^{3}$ 
Therefore, this stresses the importance of the physical therapy professional's understanding of roles in order to optimize healthcare delivery and intraprofessional collaboration. ${ }^{3}$

Teamwork is the level of willingness to cooperate, coordinate, and communicate while focused on the goal or outcome. ${ }^{4}$ Collaboration impacts the collective team in the clinic setting. ${ }^{5}$ This in turn will have implications on physical therapy intraprofessional role and responsibilities. ${ }^{6}$ Teamwork, when conducted within same disciplines, produces a working process, and the outcomes are intraprofessional by the nature of the two roles functioning collaboratively. ${ }^{2}$ Within the Canadian medical literature, collaboration is used in both inter- and intraprofessional education and practice. Intraprofessionalism is included "under the broad umbrella of collaboration" according to Bainbridge and Nasmith. ${ }^{7}$ Intraprofessionalism is occurring within teamwork and collaborative activities labelled or described in interprofessional terms and tools. The link between intraprofessionalism and interprofessionalism can be made as a result of the development of collaboration that is common to both. From an educational standpoint, the four competency domains of interprofessional education (IPE), values and ethics for practice, roles and responsibilities, communication, and teamwork, articulate similar goals or expectations. ${ }^{7}$ In this study, the link between intraprofessional educational components and interprofessional elements is a result of alignment of roles, perspectives, activities, and terms.

The two roles within PT as described in the literature is termed intraprofessionalism. ${ }^{8}$ From the perspective of this study and as one gathers an understanding of prescribed scopes of practice, the PT is an "autonomist" the PTA is an "interventionist." The "interventionist" practicing under the supervision of the "autonomist" expresses the notion of intraprofessionalism, meaning collaboration around the differences of each other's roles and duties. The need for an effective training strategy regarding the role of the PT and PTA in a collaborative work setting combined with the concept of intraprofessionalism was the area of interest that started the prerequisite work for this inquiry. For the purpose of this study, the required interaction between the two roles within PT is collaborative interprofessionalism. Health science education programs teaching in alignment with the recent interprofessional healthcare mandates across disciplines influenced the structural model example behind this bi-program activity and study premise. ${ }^{9-11}$

An activity was developed from the topics offered within the APTA on-line Learning Center, Professionalism On-line Course Series. ${ }^{12}$ The model of using an activity based on professionalism topics created a level of interaction and discussion similar to that taking place in the workforce consciously and unconsciously. The Institute of Medicine (IOM) addressed the inclusion of competency based core topics within curricula especially as IPE mandates require the elevation of academic content focusing quality cross discipline collaboration. ${ }^{13}$ The activity introduced a level playing field in terms of complexity of physical therapy training, general knowledge base, entry-level degree, and developmental stage within the professional sequence. The topic assignments are listed in Table 16.

The hypothesis for this study is that the physical therapy student studying at the PTA and DPT levels will acquire teamwork and collaboration skills within an intraprofessional academic learning opportunity. Furthermore, the purpose of this mixed methods approach is to examine the DPT and the PTA students' readiness to collaborate, and to explore what skills they possess. The study will determine if a collaborative classroom activity in the academic setting may be effective in the development of the teamwork and collaborative skills necessary for PT and PTA intraprofessionalism. The data and outcomes derived will give insight into the student perspective of and skill level in collaboration. The operational definitions for this study were taken from the framework provided by the APTA professionalism series. ${ }^{12}$ The class assignment is intended to support the efforts of the collaborative and physical therapy specific descriptions provided in the professionalism series. Figure 1 conceptualizes the premise of this study; intraprofessional physical therapy education impacting interprofessional practice collaboration with the ultimate outcome of patient-centered care.

(C) The Internet Journal of Allied Health Sciences and Practice, 2017 
Figure 1: Intraprofessional/Interprofessional Education

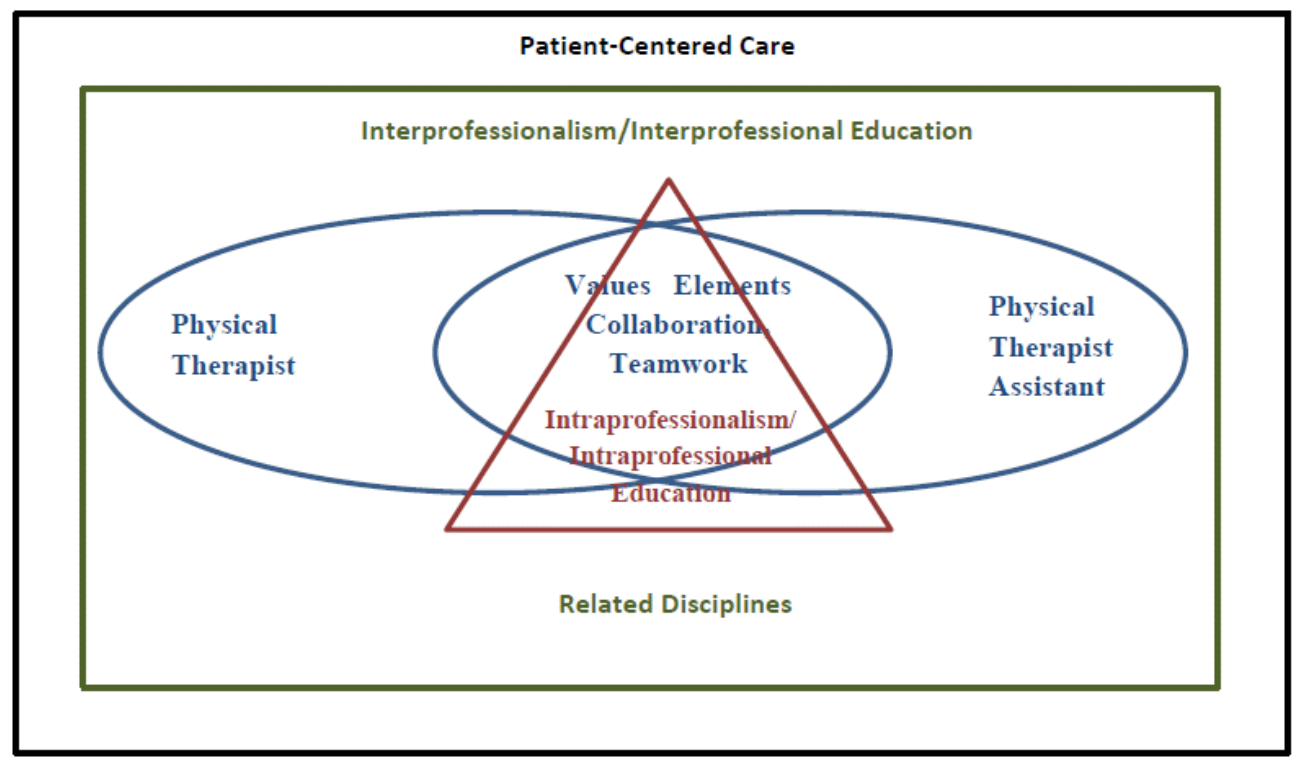

\section{LITERATURE REVIEW}

Ineffective communication and collaboration among health care providers limits the ability to improve the current healthcare environment that stresses patient safety and the reduction of medical costs. ${ }^{14}$ Health care professionals must be able to collaborate and work well together in order to have a positive effect on patient care outcomes. There is evidence to support that teamwork and collaboration skills are not intuitive and are traditionally learned with "on the job" training. ${ }^{15}$ The development of team skills is not easily acquired and demands conscious learning and practice. ${ }^{16}$ Students in general do not witness this type of collaboration and problem solving until they are working in their field.

Stemming from available professionalism education frameworks, the introduction of interprofessional education (IPE) provides opportunities for learners from various healthcare disciplines to build a solid foundation of understanding upon which future partnerships can be established. ${ }^{17}$ IPE is a mechanism used to improve the ability of professionals to engage in the collaborative process. ${ }^{18}$ It has been shown to provide students with the ability to improve upon communication skills, foster respect, enhance teamwork, and increase the understanding of roles across health care, all while promoting continuity of care. ${ }^{19}$ Quality IPE characteristics consist of common learning across professions, discussions of similarities and differences within their disciplines, and interactive, reflective learning that promotes role understanding with the importance of working together. ${ }^{20}$

Previous IPE studies have shown that students who participate in IPE demonstrated a greater appreciation and understanding of the priorities, tools, and types of interventions that are used by health care professionals in other fields. ${ }^{21}$ Not only do students gain better knowledge of their own roles and responsibilities, they also realize some of the limits of their own discipline. ${ }^{22}$ This enhanced understanding of their roles leads to better patient outcomes as turf wars and duplication of care are avoided and team functioning increases. $^{22,23}$

Collaboration, teamwork, and communication are the characteristics of interprofessional education for both practitioners and students. According to Bainbridge and Naismith, collaboration is the common thread that links interprofessionalism to the concept of intraprofessionalism taking place among team members of a single discipline. ${ }^{7}$

Recognizing collaboration in the midst of team and educational activities makes it possible to conceive that collaboration and interprofessionalism are interchangeable descriptors. ${ }^{24}$ Intraprofessionalism has been discussed in the literature minimally and mainly qualitatively. Intraprofessionalism within the IPE process can be triangulated where collaboration has meaning derived from the quantitative tool results. The most recent literature describing intraprofessionalism includes core competencies that outline qualitative behavior expectation. ${ }^{7,25}$ Intraprofessionalism education is also a mechanism used to improve the ability of students and professionals to engage in the collaborative process.

Addressing the within-discipline issues before directing collaborative efforts does not occur frequently. ${ }^{3}$ Within profession relationships established during the academic process would create a foundation for appreciation of roles and clinical support. ${ }^{3}$ 
Jung et al discusses that occupational therapy (OT) professionals struggle with articulating the defined delineation of the occupational therapist and the occupational therapist assistant roles amongst themselves and the general public. This dilemma for the PT and PTA is mirrored in articles examining their relationship in clinical education.,24 Successful intraprofessional relationships are fostered by the development of skills necessary for collaborative practice prior to graduation. ${ }^{2,24,26}$ Colgrove et al sought to examine the potential for better role understanding of the PTA in the classroom outside of the clinical education experience by using case-based activities within an academic setting. ${ }^{26}$ The solution to the lack of definition and the prospect of collaboration lies in "educat[ing] the student[s] at the professional and assistant level" simultaneously within a clinical or classroom setting. $2,24,26,27$

The choice within this study to use APTA content and behaviors derived from IPE and new intraprofessional education core content was meant to explore the existence of intraprofessionalism between PT and PTA students. To provide an educational activity that would be a model for students to acquire the necessary skills to contribute to an interprofessional team is the hypothesis of this study and speaks to the lack of formal concepts and specific training. Additionally, the gap in the literature regarding same discipline collaboration and teamwork leaves open the discussion of effective and efficient utilization of each level of the profession that would ultimately coordinate patient care, produce positive patient outcomes, and create a long term economic benefit.

\section{METHODS}

This study follows an explanatory sequential mixed methods approach where quantitative and qualitative data were collected at three stages within the coursework. ${ }^{28}$ The value of the mixed methods approach to study IPE "examin[ing] university-based... prelicensure allied health curricula" was discussed in a systematic review by Olson and Bialocerkowski. ${ }^{29}$ Factors such as student socioeconomic and "cultural backgrounds" are all subject characteristics that contributed to their qualitative responses and quantitative outcomes. Capturing these factors embodied the explanatory and sequential data lay out particular to this study. ${ }^{29}$

\section{Subjects}

The subjects were gathered from the Springfield College (SC), Doctor of Physical Program (DPT) and the Springfield Technical Community College (STCC), Physical Therapist Assistant Program (PTA), Springfield Massachusetts. The Institutional Review Board of both institutions provided approval for this project. A total of 54 students were recruited from class registrants. Eighteen PTA students and 36 DPT students participated in the study. The DPT students were in the first year of their professional program, year one of three. The PTA students were in the last year of their professional program, year two of two. Consent included participation, use of the students' coursework, and any deliverables as a result of the course assignment.

\section{Instrumentation}

The Interdisciplinary Education Perception Scale (IEPS), Table 1, and the Readiness for Interprofessional Learning Scale (RIPLS), Table 2, were completed by the subjects pre/post class project. ${ }^{30,31}$ The RIPLS contained 19 items where responses were rated on a Likert Scale, one to five, strongly agree to strongly disagree. The RIPLS subscales include 1) Teamwork and Collaboration, 2) Professional Identity, and 3) Roles and Responsibilities. ${ }^{30}$ The IEPS was a similar tool containing 18 items, a one to six Likert Scale response mechanism, strongly disagree to strongly agree. The subscales for the IEPS include 1) Competency and Autonomy, 2) Perceived Need for Cooperation, and 3) Perception of Actual Cooperation. Both of these tools were developed to be used in an academic context. ${ }^{31}$

A third tool, the Performance Evaluation, was developed by the researchers to capture individual student ratings of the process. This tool asked students to reflect on the performance of themselves and group members in order to examine student engagement. ${ }^{32}$ The Performance Evaluation questions consisted of 17 items divided into three subcategories: 1) Responsibilities, 2) Collaboration, and 3) Synthesis. These subcategories relate by definition to the PT and PTA values documents and collaboration skills. 33,34 Using a Likert scale ranging from one to five, the descriptors included never performed (1) to consistently performed (5). Space was also provided for subjective comments at each question. Using this form, each subject completed a self-evaluation and separate evaluations for each group member. Table 3 offers a brief description of each category.

Qualitative data were gathered via 1) demographic job data noting previous supervisory or leadership experience, 2) subjective comments on the Performance Evaluation, 3) field/meeting notes completed by each group as they prepared for the presentation, and 4) faculty grading rubric. Faculty comments were included in the grading rubric. Each faculty member documented individually per presentation and compared comments only at data analysis. Field notes were completed using a template form that provided suggestions for meeting organization and focus. An area to document additional strategies conducted by the student group was also provided.

(C) The Internet Journal of Allied Health Sciences and Practice, 2017 


\section{Procedure}

Learning objectives were determined separately following institutional standards for the corresponding courses within the DPT and PTA curricula. Following A Normative Model of Physical Therapist Professional Education and A Normative Model of Physical Therapist Assistant Education, ${ }^{35,36}$ similar overarching themes were evident. The learning objectives for the courses:

1. Appreciate that their individual background, personal history, and development has formed their unique perception of the world (STCC)

2. Accept responsibility for one's role as a team member (STCC)

3. Discuss the current events related to physical therapy practice, health care reform and health care legal issues (SC and STCC)

4. Discuss and differentiate the various health care roles in rehabilitation (SC and STCC)

5. Given a simulated physical therapist interaction, identify and apply nonverbal and verbal communication skills appropriate to the scenario. (SC)

Stage 1: A lecture introduced physical therapy professional practice, intraprofessional practice theories, and related professional practice content to a combined class of PT and PTA students. During the class, demographic information was obtained from each student. Qualitative information was collected regarding the subjects' previous experience of being in a supervisory or leadership role. The subjects also completed the two surveys: the Readiness for Interprofessional Learning Scale (RIPLS) and the Interdisciplinary Education Perception Scale (IEPS). $19,31,30$

The students were then assigned to one of twelve small groups. Group selection was random, but the distribution of PT to PTA within each group was stratified because of the inequity in program numbers. Each group contained a combination of 3 or 4 DPT students and 1 or 2 PTA students. The small group size was established to facilitate learning, knowledge acquisition, communication, teamwork, and problem solving. A focus on independent responsibility for learning, the attempt to foster sharing information, and respect for others were additional goals of the small group formation. ${ }^{37}$

A professional topic was assigned randomly to each group. Each group was assigned a professional practice topic to research and present on at the end of the semester. The topics were adapted from the APTA on-line course series on professionalism and are listed under "Group Assignments" in Table 16.12 The subjects within their groups were responsible for the organization of group meetings and the determination of the actual task to be addressed and/or completed within each meeting. The groups were required to log field notes/meeting minutes regarding the structure, proceedings, and outcome of each meeting. The field notes were then posted throughout the semester to either institutional site, Blackboard, or Moodle depending upon the preference of the scribe for each group.

Stage 2: Students attended the MA APTA Western District sponsored event. A two-fold event that included 1) presentation from the President of the Massachusetts APTA, and 2) A PT/PTA panel detailing working teams in multiple care settings.

Stage 3: The final event was the class presentation day. Each small group was given 15 minutes to present to the combined class. Faculty evaluations were completed by using a developed grading rubric including quantitative and qualitative items. The postclass activity components of the RIPLS and IEPS were also completed at this time. The peer and self-evaluation were completed via survey monkey at student convenience before the end of the semester.

\section{Faculty Observations}

Observations from the faculty were assessed from evaluation of presentations during the final class and not specifically used as a data point. 
Table 1: Interdisciplinary Education Perception Scale: Pre/Post

You will be asked to complete this at the beginning and end of your placement. Thanks for your assistance Mother's date of birth (to allow us to match pre and post responses):

Using the scale below, please rate your perception of your profession and other disciplines.

\begin{tabular}{|c|c|c|c|c|c|c|}
\hline Descriptor & $\begin{array}{l}\text { Strongly } \\
\text { Disagree } \\
1\end{array}$ & $\begin{array}{l}\text { Moderately } \\
\text { Disagree } \\
2\end{array}$ & $\begin{array}{c}\text { Somewhat } \\
\text { Disagree } \\
3\end{array}$ & $\begin{array}{l}\text { Somewhat } \\
\text { Agree } \\
4\end{array}$ & $\begin{array}{l}\text { Moderately } \\
\text { Agree } \\
5\end{array}$ & $\begin{array}{l}\text { Strongly } \\
\text { Agree } \\
6\end{array}$ \\
\hline \multicolumn{7}{|l|}{ 1. Individuals in my profession are well-trained. } \\
\hline \multicolumn{7}{|l|}{$\begin{array}{l}\text { 2. Individuals in my profession are able to work } \\
\text { closely with individuals in other professions }\end{array}$} \\
\hline \multicolumn{7}{|l|}{$\begin{array}{l}\text { 3. Individuals in my profession demonstrate a great } \\
\text { deal of autonomy }\end{array}$} \\
\hline \multicolumn{7}{|l|}{$\begin{array}{l}\text { 4. Individuals in other professions respect the work } \\
\text { done by my profession }\end{array}$} \\
\hline \multicolumn{7}{|l|}{$\begin{array}{l}\text { 5. Individuals in my profession are very positive } \\
\text { about their goals and objectives }\end{array}$} \\
\hline \multicolumn{7}{|l|}{$\begin{array}{l}\text { 6. Individuals in my profession need to cooperate } \\
\text { with other professions }\end{array}$} \\
\hline \multicolumn{7}{|l|}{$\begin{array}{l}\text { 7. Individuals in my profession are very positive } \\
\text { about their contributions and accomplishments }\end{array}$} \\
\hline \multicolumn{7}{|l|}{$\begin{array}{l}\text { 8. Individuals in my profession must depend upon } \\
\text { the work of people in other professions }\end{array}$} \\
\hline \multicolumn{7}{|l|}{$\begin{array}{l}\text { 9. Individuals in other professions think highly of my } \\
\text { profession }\end{array}$} \\
\hline \multicolumn{7}{|l|}{$\begin{array}{l}\text { 10. Individuals in my profession trust each other's } \\
\text { professional judgment }\end{array}$} \\
\hline \multicolumn{7}{|l|}{$\begin{array}{l}\text { 11. Individuals in my profession have a higher status } \\
\text { than individuals in other professions }\end{array}$} \\
\hline \multicolumn{7}{|l|}{$\begin{array}{l}\text { 12. Individuals in my profession make every effort to } \\
\text { understand the capabilities and contributions of other } \\
\text { professions }\end{array}$} \\
\hline \multicolumn{7}{|l|}{$\begin{array}{l}\text { 13. Individuals in my profession are extremely } \\
\text { competent }\end{array}$} \\
\hline \multicolumn{7}{|l|}{$\begin{array}{l}\text { 14.Individuals in my profession are willing to share } \\
\text { information and resources with other professionals }\end{array}$} \\
\hline \multicolumn{7}{|l|}{$\begin{array}{l}\text { 15. Individuals in my profession have good relations } \\
\text { with people in other professions }\end{array}$} \\
\hline \multicolumn{7}{|l|}{$\begin{array}{l}\text { 16. Individuals in my profession think highly of other } \\
\text { related professions }\end{array}$} \\
\hline \multicolumn{7}{|l|}{$\begin{array}{l}\text { 17. Individuals in my profession work well with each } \\
\text { other }\end{array}$} \\
\hline $\begin{array}{l}\text { 18. Individuals in other professions often seek the } \\
\text { advice of people in my profession }\end{array}$ & & & & & & \\
\hline
\end{tabular}


Table 2 Readiness for Interprofessional Learning Scale (RIPLS) Questionnaire

\begin{tabular}{|c|c|c|c|c|c|c|}
\hline & $\begin{array}{l}\text { The purpose of this questionnaire is to examine the attitude of } \\
\text { health and social care students and professionals towards } \\
\text { interprofessional learning }\end{array}$ & $\begin{array}{l}\text { Strongly } \\
\text { Agree }\end{array}$ & Agree & Undecided & Disagree & $\begin{array}{l}\text { Strongly } \\
\text { Disagree }\end{array}$ \\
\hline 1. & $\begin{array}{l}\text { Learning with other students/professionals will make me a } \\
\text { more effective member of a health and social care team }\end{array}$ & & & & & \\
\hline 2. & $\begin{array}{l}\text { Patients would ultimately benefit if health and social care } \\
\text { students/professionals worked together }\end{array}$ & & & & & \\
\hline 3. & $\begin{array}{l}\text { Shared learning with other health and social care } \\
\text { students/professionals will increase my ability to understand } \\
\text { clinical problems }\end{array}$ & & & & & \\
\hline 4. & $\begin{array}{l}\text { Communications skills should be learned with other health and } \\
\text { social care students/professionals }\end{array}$ & & & & & \\
\hline 5. & $\begin{array}{l}\text { Team-working skills are vital for all health and social care } \\
\text { students/professionals to learn }\end{array}$ & & & & & \\
\hline 6. & $\begin{array}{l}\text { Shared learning will help me to understand my own } \\
\text { professional limitations }\end{array}$ & & & & & \\
\hline 7. & $\begin{array}{l}\text { Learning between health and social care students before } \\
\text { qualification and for professionals after qualification would } \\
\text { improve working relationships after qualification/collaborative } \\
\text { practice. }\end{array}$ & & & & & \\
\hline 8. & $\begin{array}{l}\text { Shared learning will help me think positively about other health } \\
\text { and social care professionals }\end{array}$ & & & & & \\
\hline 9. & $\begin{array}{l}\text { For small-group learning to work, students/professionals need } \\
\text { to respect and trust each other }\end{array}$ & & & & & \\
\hline 10. & $\begin{array}{l}\text { I don't want to waste time learning with other health and social } \\
\text { care students/professionals }\end{array}$ & & & & & \\
\hline 11. & $\begin{array}{l}\text { It is not necessary for undergraduate/postgraduate health and } \\
\text { social care students/professionals to learn together }\end{array}$ & & & & & \\
\hline 12. & $\begin{array}{l}\text { Clinical problem solving can only be learnt effectively with } \\
\text { students/professionals from my own school/organization }\end{array}$ & & & & & \\
\hline 13. & $\begin{array}{l}\text { Shared learning with other health and social care } \\
\text { professionals will help me to communicate better with patients } \\
\text { and other professionals }\end{array}$ & & & & & \\
\hline 14. & $\begin{array}{l}\text { I would welcome the opportunity to work on small group } \\
\text { projects with other health and social care } \\
\text { students/professionals }\end{array}$ & & & & & \\
\hline 15. & $\begin{array}{l}\text { I would welcome the opportunity to share some generic } \\
\text { lectures, tutorials or workshops with other health and social } \\
\text { care students/professionals }\end{array}$ & & & & & \\
\hline 16. & $\begin{array}{l}\text { Shared learning and practice will help me clarify the nature of } \\
\text { patients' or clients' problems }\end{array}$ & & & & & \\
\hline 17. & $\begin{array}{l}\text { Shared learning before and after qualification will help me } \\
\text { become a better team worker }\end{array}$ & & & & & \\
\hline 18. & I am not sure what my professional role will be/is & & & & & \\
\hline 19. & $\begin{array}{l}\text { I have to acquire much more knowledge and skill than other } \\
\text { students/professionals in my own faculty/organization }\end{array}$ & & & & & \\
\hline
\end{tabular}

If you have any further comments regarding interprofessional education please enter them below: 
Table 3: Performance Evaluation

\begin{tabular}{|c|c|c|c|c|c|}
\hline \multicolumn{6}{|c|}{ Springfield College/Springfield Community Technical College Collaborative Presentation Performance Evaluation Form } \\
\hline \multicolumn{6}{|c|}{ Evaluator Name: $\quad$ Self $\square$ Peer $\square$ Peer Name $\square$} \\
\hline \multicolumn{6}{|c|}{ Complete the evaluation for: A) $s$} \\
\hline \multicolumn{6}{|c|}{$\begin{array}{l}\text { Place a circle around the value (number) that be } \\
\text { performance demonstrated. }\end{array}$} \\
\hline \multicolumn{6}{|c|}{$\begin{array}{l}\text { The evaluation is designed to discuss the performance of self/peer } c \\
\text { presentation/collaborative event. }\end{array}$} \\
\hline \multicolumn{5}{|c|}{ Effectively organizes and prepares material for each meeting with appropriate relevance, breadth, and depth. } & Value: \\
\hline \multirow{2}{*}{\multicolumn{5}{|c|}{$\begin{array}{ccccc}1 & 2 & 3 & 4 & 5 \\
\text { Never } & \text { Rarely } & \text { Occasionally } & \text { Often } & \text { Consistently }\end{array}$}} & \\
\hline & & & & & Term: \\
\hline \multicolumn{5}{|c|}{ Presents and interjects researched material to facilitate and promote task completion. } & Value: \\
\hline \multicolumn{5}{|c|}{$\begin{array}{ccccc}1 & 2 & 3 & 4 & 5 \\
\text { Never } & \text { Rarely } & \text { Occasionally } & \text { Often } & \text { Consistently }\end{array}$} & Term: \\
\hline \multirow{3}{*}{\multicolumn{5}{|c|}{$\begin{array}{l}\text { Contributes to discussion of other's material in a way that demonstrates familiarity with and preparation across group tasks. } \\
\begin{array}{ccccc}1 & 2 & 3 & 4 & 5 \\
\text { Never } & \text { Rarely } & \text { Occasionally } & \text { Often } & \text { Consistently }\end{array}\end{array}$}} & Value: \\
\hline & & & & & \\
\hline & & & & & Term: \\
\hline \multicolumn{5}{|c|}{$\begin{array}{l}\text { Synthesizes and integrates group information to facilitate project completion and flow of each meeting } \\
\text { (e.g. poses appropriate questions, ties together information, raises new or unresolved issues). }\end{array}$} & Value: \\
\hline \multicolumn{5}{|c|}{$\begin{array}{ccccc}1 & 2 & 3 & 4 & 5 \\
& 2 & & \end{array}$} & Term: \\
\hline \multicolumn{5}{|c|}{ Appropriately questions opinion or theory presented by other group members during presentation preparation meetings. } & Value: \\
\hline \multicolumn{5}{|c|}{$\begin{array}{ccccc}1 & 2 & 3 & 4 & 5 \\
\text { Never } & \text { Rarely } & \text { Occasionally } & \text { Often } & \text { Consistently }\end{array}$} & Term: \\
\hline \multicolumn{5}{|c|}{ Provides support and encouragement to other group members. } & Value: \\
\hline \multicolumn{5}{|c|}{$\begin{array}{ccccc}1 & 2 & 3 & 4 & 5 \\
\text { Never } & \text { Rarely } & \text { Occasionally } & \text { Often } & \text { Consistently } \\
\end{array}$} & Term: \\
\hline \multicolumn{5}{|c|}{ Responds appropriately to feedback from others. } & Value: \\
\hline \multicolumn{5}{|c|}{$\begin{array}{ccccc}1 & 2 & 3 & 4 & 5 \\
\text { Never } & \text { Rarely } & \text { Occasionally } & \text { Often } & \text { Consistently }\end{array}$} & Term: \\
\hline \multicolumn{5}{|c|}{ Interacts in a respectful and constructive manner with others. } & Value: \\
\hline \multicolumn{5}{|c|}{$\begin{array}{ccccc}1 & 2 & 3 & 4 & 5 \\
\text { Never } & \text { Rarely } & \text { Occasionally } & \text { Often } & \text { Consistently }\end{array}$} & Term: \\
\hline \multicolumn{5}{|c|}{ Makes a complementary contribution to group process. } & Value: \\
\hline \multicolumn{5}{|c|}{$\begin{array}{ccccc}1 & 2 & 3 & 4 & 5 \\
\text { Never } & \text { Rarely } & \text { Occasionally } & \text { Often } & \text { Consistently }\end{array}$} & Term: \\
\hline & Value: \\
\hline \multicolumn{5}{|c|}{\begin{tabular}{lcccc}
\multicolumn{4}{l}{ Made major creative contributions, adding an important perspective. } \\
1 & 2 & 3 & 4 & 5 \\
Never & Rarely & Occasionally & Often & Consistently
\end{tabular}} & Term: \\
\hline \multirow{2}{*}{\multicolumn{5}{|c|}{ 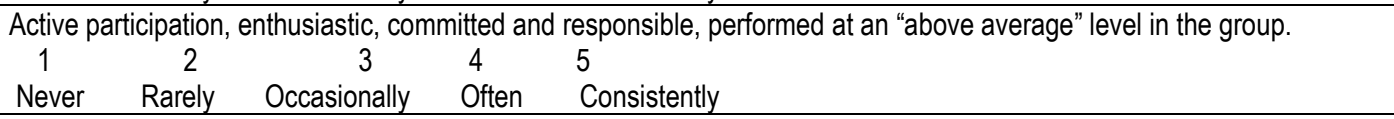 }} & Value: \\
\hline & & & & & Term: \\
\hline \multirow{2}{*}{\multicolumn{5}{|c|}{$\begin{array}{l}\text { Takes the initiative to move the group members in a new direction in response to the group process. } \\
\begin{array}{lllll}1 & 2 & 3 & 4 & 5 \\
\text { Never } & \text { Rarely } & \text { Occasionally } & \text { Often } & \text { Consistently }\end{array}\end{array}$}} & Value: \\
\hline & & & & & Term: \\
\hline Provide & reminders & f responsibilities & due da & es, or meeting times. & Value: \\
\hline & $\begin{array}{c}2 \\
\text { Rarely }\end{array}$ & $\begin{array}{c}3 \\
\text { Occasionally } \\
\end{array}$ & & $\begin{array}{l}5 \\
\text { Consistently }\end{array}$ & Term: \\
\hline Provide & major ene & y and leadershi & for the & roup and during group meetings. & Value: \\
\hline $\begin{array}{c}1 \\
\text { Never }\end{array}$ & $\begin{array}{c}2 \\
\text { Rarely }\end{array}$ & $\begin{array}{c}3 \\
\text { Occasionally }\end{array}$ & $\begin{array}{l}4 \\
\text { Often }\end{array}$ & $\begin{array}{l}5 \\
\text { Consistently }\end{array}$ & Term: \\
\hline Follows & rough on & esponsibilities w & hout pro & npting. & Value: \\
\hline $\begin{array}{c}1 \\
\text { Never }\end{array}$ & $\begin{array}{c}2 \\
\text { Rarely }\end{array}$ & $\begin{array}{c}3 \\
\text { Occasionally }\end{array}$ & $\begin{array}{l}4 \\
\text { Often }\end{array}$ & $\begin{array}{l}5 \\
\text { Consistently }\end{array}$ & Term: \\
\hline Self-dir & ted in pre & ration for the gr & up mee & ng tasks and overall presentation project. & Value: \\
\hline $\begin{array}{c}1 \\
\text { Never }\end{array}$ & $\begin{array}{c}2 \\
\text { Rarely }\end{array}$ & $\begin{array}{c}3 \\
\text { Occasionally }\end{array}$ & $\begin{array}{l}4 \\
\text { Often }\end{array}$ & $\begin{array}{l}5 \\
\text { Consistently }\end{array}$ & Term: \\
\hline Willing & work with & is team/team $\mathrm{m}$ & mber o & other projects or activities. & Value: \\
\hline $\begin{array}{c}1 \\
\text { Never }\end{array}$ & $\begin{array}{c}2 \\
\text { Rarely }\end{array}$ & $\begin{array}{c}3 \\
\text { Occasionally }\end{array}$ & $\begin{array}{l}4 \\
\text { Often }\end{array}$ & $\begin{array}{l}5 \\
\text { Consistently }\end{array}$ & Term: \\
\hline
\end{tabular}


Accomplishments (Self or Team process)

Challenges and unmet goals (Self or Team process)

\section{Data Analysis}

Quantitative data analyses were completed using the SPSS Statistics for Windows Version 21.0. Qualitative analysis was conducted using a $Q$ - sort method in Excel. Findings in the form of student comments were aggregated and synthesized into themes. Themes were identified for the individual experiences of supervision and delegation by the individual student and the group performances.

\section{RESULTS}

\section{RIPLS}

A total of 54 (36 DPT, 18 PTA) students participated in the survey. Analysis was conducted calculating separate by program statistics, pre/post comparisons and descriptive total values. Preliminary data screening revealed significant correlations between means of RIPLs subscales except for one.

\begin{tabular}{|l|l|l|}
\multicolumn{3}{c}{ Table 4 RIPLS Subcategories 38} \\
\hline \multicolumn{1}{|c|}{ Question Item } & Subcategories & Description \\
\hline $1-8$ & $\begin{array}{l}\text { Teamwork \& } \\
\text { Collaboration }\end{array}$ & $\begin{array}{l}\text { Effective team-working } \\
\text { Relationships with other professionals }\end{array}$ \\
\hline $9-17$ & Professional Identity & $\begin{array}{l}\text { Negative \& Positive professional identity perspectives } \\
\text { Importance attached to identity acquisition }\end{array}$ \\
\hline 18,19 & $\begin{array}{l}\text { Roles \& } \\
\text { Responsibilities }\end{array}$ & Boundaries of delineated roles and professional practice \\
\hline
\end{tabular}

Teamwork and Collaboration was not significantly correlated to Roles \& Responsibilities $(r=-.060, p=.666)$. Other intercorrelations between variables ranged from .305 to .320 with no correlations between outcome variables large enough to indicate multicollinearity.

Table 5 RIPLS Subscale Scores
\begin{tabular}{|l|l|l|l|l|}
\hline \multicolumn{1}{|c|}{ Subscale } & \multicolumn{2}{c|}{$\boldsymbol{n}$} & \multicolumn{1}{c|}{ Mean Score } & Std. Deviation \\
\hline Teamwork \& Collaboration & Pre & 54 & 4.4856 & 0.40949 \\
\hline & Post & 54 & 4.6490 & 0.32279 \\
\hline Professional Identity & Pre & 54 & 3.4375 & 0.23678 \\
\hline & Post & 54 & 3.4423 & 0.20028 \\
\hline Roles \& Responsibilities & Pre & 54 & 2.4423 & 0.77746 \\
\hline & Post & 54 & 2.2692 & 0.63756 \\
\hline
\end{tabular}

Other preliminary data screening revealed a slight violation of the basic assumption of univariate homogeneity. Levene's test indicated homogeneity among groups for the subscales Professional Identity pretest $(p=.717)$ and posttest $(p=.897)$, Roles and Responsibilities pretest $(p=.413)$ and posttest $(p=.223)$, and Teamwork and Collaboration posttest $(p=.184)$, but not for Teamwork and Collaboration pretest $(p=.026)$. Box's $M$ test confirms homogeneity of variance/covariance matrices across groups $(p=.128)$. Basic Assumptions are summarized in Table 6.

\begin{tabular}{|c|c|c|c|}
\hline \multicolumn{4}{|c|}{ Table 6 Basic Assumptions for the RIPLS $2 \times 2$ Mixed Factorial MANOVA } \\
\hline Variables & Levene's Test & $F$ ratio & $p$ \\
\hline \multicolumn{4}{|l|}{ Pretest } \\
\hline Teamwork \& Collaboration & & 5.25 & .03 \\
\hline Roles \& Responsibilities & .68 & .41 & \\
\hline Professional Identity & & .13 & .72 \\
\hline \multicolumn{4}{|l|}{ Posttest } \\
\hline Teamwork \& Collaboration & & 1.82 & .18 \\
\hline Roles \& Responsibilities & & .51 & .61 \\
\hline Professional Identity & 1.52 & .22 & \\
\hline
\end{tabular}


Box $M F$ ratio $=1.34, p=.13$

A $2 \times 2$ mixed factorial MANOVA was conducted to assess the effects of program on the mean vector of pre and posttest scores on RIPLS subscales. Results are as follows. No significant interaction existed between program and pretest/posttest for the mean vector of RIPLS subscales $\left(\Lambda=.948, p=.463, \eta^{2}=.052\right)$. The main effect of program on the mean vector of RIPLS subscales was significant with Wilk's $\Lambda=.788, p=.009$. Approximately $21 \%$ of the variance in RIPLS subscales was explained by differences in program. The main effect of pretest vs. posttest was also significant with Wilk's $\Lambda=.845, p=.042$. Approximately $16 \%$ of the variance in RIPLS subscales was explained by differences between pretest and posttest.

A discriminant function analysis was performed for the effect of program. Because there were 2 groups, one discriminant function was created with a canonical correlation of .474, indicating moderate correlation with program, and a significant chi square, $X^{2}(3)$ $=12.836, p=.005$. Using an arbitrary cutoff of .5 , only Roles and Responsibilities had large enough structure coefficients (see Table 7). However, both Roles and Responsibilities and Teamwork and Collaboration had standardized canonical discriminant function coefficients above the cutoff. Based on the function, those who scored higher were more likely to be classified as PT, and those who scored lower were more likely to be classified as PTA. Overall, $74 \%$ of the participants were correctly classified into the right program by the discriminant function.

Table 7: Discriminant Function Analysis to Determine Differences in Programs from Scores on RIPLs Subscales

\begin{tabular}{|l|c|c|c|c|c|}
\hline \multicolumn{1}{|c|}{ Variable } & Wilks' Lambda & $\mathbf{p}$ & Unstand Coeffs. & Stand. Coeffs. & Structure Coeffs. \\
\hline $\begin{array}{l}\text { Roles \& } \\
\text { Responsibilities }\end{array}$ & .82 & .00 & 1.43 & .81 & .87 \\
\hline $\begin{array}{l}\text { Teamwork \& } \\
\text { Collaboration }\end{array}$ & .96 & .15 & -1.57 & -.51 & -.38 \\
\hline Constant & & & & & -2.67 \\
\hline
\end{tabular}

Polynomial contrasts were used to assess differences between pretest and posttest scores for RIPLs subscales. Linear significance existed for the subscale, Teamwork and Collaboration $(p=.004)$, but not for Professional Identity $(p=.785)$ or Roles and Responsibilities $(p=.269)$. Teamwork and Collaboration increased significantly from pretest to posttest. Polynomial contrasts are shown in Table 8.

Table 8 Polynomial Trend Analysis for Pre-test and Post-test Scores for the RIPLS subscales

\begin{tabular}{|l|l|l|l|}
\hline \multicolumn{1}{|c|}{ Subscale } & \multicolumn{1}{c|}{$\boldsymbol{F}$} & $\boldsymbol{p}$ & $\boldsymbol{\eta}^{2}$ \\
\hline Teamwork and Collaboration & \multicolumn{1}{c|}{ ( } & & \\
\hline Linear & 9.07 & .00 & .15 \\
\hline Professional Identity & & & \\
\hline Linear & .08 & .79 & .00 \\
\hline Roles and Responsibilities & & & \\
\hline Linear & .42 & .27 & .02 \\
\hline
\end{tabular}

\section{IEPS}

A total of 54 students (36 PT, 18 PTA) participated in the survey. Preliminary data screening revealed significant correlations between means of IEPS subscales Competence and Autonomy, Perceived Need for Cooperation, and Perception of actual Cooperation.

Table 9 IEPS Subcategories ${ }^{31,39}$

\begin{tabular}{|l|l|l|}
\hline \multicolumn{1}{|c|}{ Question Item } & \multicolumn{1}{c|}{ Subcategories } & \multicolumn{1}{c|}{ Description } \\
\hline $1,5,7,10,13$ & $\begin{array}{l}\text { Competence and } \\
\text { Autonomy }\end{array}$ & $\begin{array}{l}\text { Professional judgement, contribution and knowledge } \\
\text { Positive perspective }\end{array}$ \\
\hline $6 \& 8$ & $\begin{array}{l}\text { Perceived Need for } \\
\text { Cooperation }\end{array}$ & $\begin{array}{l}\text { Dependability } \\
\text { Interprofessionalism }\end{array}$ \\
\hline $2,14,15,16,17,18$ & $\begin{array}{l}\text { Perception of actual } \\
\text { Cooperation }\end{array}$ & $\begin{array}{l}\text { Collaboration and relationships } \\
\text { Camaraderie }\end{array}$ \\
\hline
\end{tabular}

Intercorrelations between dependent variables ranged from .464 to .814 , which may have indicated multicollinearity between the subscales Competence and Autonomy and Perception of Actual Cooperation $(r=.814)$. Other preliminary data screening revealed 
a slight violation of the basic assumption of univariate homogeneity. Levene's test indicated homogeneity among groups for the subscales Perceived Need for Cooperation pretest $(p=.127)$ and posttest $(p=.128)$, Competence and Autonomy posttest $(p=$ .119 ), and Perception of Actual Cooperation posttest $(p=.279)$, but not for Competence and Autonomy pretest $(p=.035)$ or Perception of Actual Cooperation pretest $(p=.001)$. Box's $M$ test was significant which indicated that the basic assumption of homogeneity of variance/covariance matrices across groups was violated $(p<.001)$.

A $2 \times 2$ mixed factorial MANOVA was conducted to assess the effect of program on the mean vector of pretest and posttest scores on IEPS subscales. Results are as follows. No significant interaction effect existed between program and pretest/posttest $(\Lambda=$ $.970, p=.672, \eta^{2}=.030$ ). No significant effect of program on the mean vector of IEPS subscales existed with Wilk's $\Lambda=.966, p=$ .624. Approximately $3 \%$ of the variance was explained by differences in program. The effect of pretest vs. posttest was also nonsignificant with Wilk's $\Lambda=.941, p=.379$. Approximately $6 \%$ of the variance in IEPS subscales was explained by differences between pretest and posttest. Therefore, no significant differences existed between programs or between pretest and posttest scores on IEPS subscales as indicated in Table 10.

Table 10 IEPS Subscale Scores

\begin{tabular}{|l|l|l|l|l|}
\hline Subscale & & $n$ & Mean Score & Std. Deviation \\
\hline Competency \& Autonomy & Pre & 54 & 5.4963 & 0.50617 \\
\hline & Post & 54 & 5.5185 & 0.71903 \\
\hline Perceived for Cooperation & Pre & 54 & 5.5185 & 0.48932 \\
\hline & Post & 54 & 5.4537 & 0.75404 \\
\hline Perception of Actual Cooperation & Pre & 54 & 5.3444 & 0.55138 \\
\hline & Post & 54 & 5.3852 & 0.75521 \\
\hline
\end{tabular}

\section{Demographic job data}

The quantitative list of the supervisory experiences of students is outlined in Table 11. The responses were in 9 major areas: sports, hospitality, health care, babysitting, retail, the trades, scholarship, volunteer, and full time professional work. Table 12 indicates that the highest frequency of experiences was distinct at one or three, six students $36 \%$ of the class and five students $30 \%$ of the class for the PTA's. The PT students were focused at one to three experiences as being the most frequent where eleven or $29 \%$ of students possessed one to two supervisory jobs or positions and nine students, $24.3 \%$, held three supervisory jobs within their work experiences contributing to this project.

Table 11 Previous Supervisory/Leadership Experiences (count/\% of class)
\begin{tabular}{|l|l|l|}
\hline \multicolumn{1}{|c|}{ PT } & \multicolumn{1}{c|}{ PTA } \\
\hline$n$ & 37 & 17 \\
\hline Sports & $24(64 \%)$ & $7(41 \%)$ \\
\hline Hospitality & $17(45.9 \%)$ & $11(65 \%)$ \\
\hline Healthcare & $3(1.11 \%)$ & $2(12 \%)$ \\
\hline Babysitting & $5(13.5 \%)$ & $2(12 \%)$ \\
\hline Retail & $3(8.1 \%)$ & $5(29.4 \%)$ \\
\hline Trade & $1(6 \%)$ & $5(13.5 \%)$ \\
\hline Scholarship & 0 & $4(10.8 \%)$ \\
\hline Volunteer & 0 & $2(5.4 \%)$ \\
\hline Professional F/T & $2(12 \%)$ & $3(8.1 \%)$ \\
\hline
\end{tabular}

Table 12 Number of Supervisory Experiences

\begin{tabular}{|l|c|l|l|l|l|l|l|l|l|l|}
\hline Population & $\boldsymbol{n}$ & \multicolumn{8}{|c|}{ Frequency of experiences (count/\% of class) } \\
\hline & & 0 & 1 & 2 & 3 & 4 & 5 & 6 & 7 & $>7$ \\
\hline PTA & 17 & $1 / 6 \%$ & $6 / 36 \%$ & $3 / 18 \%$ & $5 / 30 \%$ & $2 / 12 \%$ & $1 / 6 \%$ & $1 / 6 \%$ & $1 / 6 \%$ & \\
\hline PT & 37 & $1 / 2.7 \%$ & $11 / 29.7 \%$ & $11 / 29.7 \%$ & $9 / 24.3 \%$ & $2 / 5.4 \%$ & 0 & $1 / 2.7 \%$ & 0 & $1 / 2.7 \%$ \\
\hline
\end{tabular}

\section{The Performance Evaluation}

Table 13 displays the combined peer and self-evaluation subcategories and descriptions as developed from theme identification via descriptive coding. Table 14 data reveals that score range and percentage of students within five defined percentiles. By 
definition and use of the evaluation, $75 \%$ of students scored a " 5 " on the Likert scale indicating "consistency" in their performance as described by peers and self. The $5 \%$ of students within the " $3-4$ " score demonstrated unacceptable performance where the "occasional to often" description of their team process revealed the variability in performance of the students.

\begin{tabular}{|l|l|l|}
\multicolumn{1}{c}{ Table 13 Performance Evaluation Subcategories } \\
\hline \multicolumn{1}{|c|}{ Question Item } & \multicolumn{1}{c|}{ Subcategories } & \multicolumn{1}{c|}{ Description } \\
\hline $1,11,13,15,16,17$ & Responsibilities & $\begin{array}{l}\text { Ownership of tasks, team process Self-directed, holds self and } \\
\text { team members accountable }\end{array}$ \\
\hline $2,3,6,8,9,10$ & Collaboration & $\begin{array}{l}\text { Engagement with team members } \\
\text { Active listener, supportive, contributor, complementary }\end{array}$ \\
\hline $4,5,7,12$ & Synthesis & $\begin{array}{l}\text { Integration, initiative, feedback } \\
\text { Characteristics of individual }\end{array}$ \\
\hline
\end{tabular}

\begin{tabular}{|c|c|c|l|l|l|l|l|}
\hline \multicolumn{1}{|c|}{ Table 14 Performance Evaluation Score by Percentile } \\
\hline Cl & Mean & SD + & \multicolumn{5}{c|}{ Percentile and Score } \\
\cline { 4 - 8 } & & & 5 & 10 & 25 & 50 & 75 \\
\hline $95 \%$ & 4.6846 & 0.52480 & 3.8824 & 4.1765 & 4.5294 & 4.8824 & 5.000 \\
\hline
\end{tabular}

The Performance Evaluation comments (Table 15) show that the majority of students are consistent within the themes of responsibility, collaboration and synthesis evident by the overall project product. Relating student descriptive comments to the score breakdown following analysis, students were very distinct in their descriptions of peer performance as aligned to the identified themes. The highest scores indicated excellence in collaboration. The small number of students who scored lowest within the Performance Evaluation process was the poor performers.

\begin{tabular}{|c|c|}
\hline & Table 15 Peer Evaluation Distinct Descriptions \\
\hline Score & $\begin{array}{l}\text { Range of Comments } \\
\end{array}$ \\
\hline \multirow[t]{5}{*}{5.0000} & $\begin{array}{l}\text { Awesome researcher. --- accomplished a large amount of research and helped the group to understand } \\
\text { that research. She also provided a great case scenario to add to the presentation. }\end{array}$ \\
\hline & $\begin{array}{l}\text { Was beyond fantastic about staying in contact with us. She was very much organized with her due dates } \\
\text { and informed us of them immediately giving us a timeline to work off of. }\end{array}$ \\
\hline & $\begin{array}{l}\text { Contributed a lot; was extremely helpful. Very smart guy when it comes to research. We accomplished } \\
\text { everything we wanted to as a group. }\end{array}$ \\
\hline & $\begin{array}{l}\text {--- was prepared for all of our meetings, and went above and beyond in his research. His work ethic was } \\
\text { admirable, and he was eager to collaborate with us during this project. }\end{array}$ \\
\hline & $\begin{array}{l}\text { Wonderful collaboration. This was a good group to be. We all were willing to work and help with our } \\
\text { project. Even though we did not meet too many times, we stayed communicated by email, and phone, and } \\
\text { achieve our goal. }\end{array}$ \\
\hline \multirow[t]{5}{*}{4.8824} & $\begin{array}{l}\text {--- completed his portion of the project ahead of schedule and used great resources to support himself. He } \\
\text { repeatedly helped other members of the group. }\end{array}$ \\
\hline & Wonderful collaboration. We all were able to help, and achieve our goal as a group. \\
\hline & $\begin{array}{l}\text { Did great; always was on top of things! } \\
\text { Great level of enthusiasm, provided much energy to group dynamic. Showed genuine interest in topic at } \\
\text { hand as well as in people he was working with. }\end{array}$ \\
\hline & $\begin{array}{l}\text { Provided creative ideas to contribute to the project as a whole, such as interviewing each professor in the } \\
\text { program who holds a specialization about why they chose to pursue the certification. Although our group } \\
\text { was unable to present this portion of the presentation due to time constraints, I thought it was a creative } \\
\text { idea to make the presentation more personal and relevant to our peers. }\end{array}$ \\
\hline & Took initial initiative to start developing majority of presentation aspects. Provided creative input. \\
\hline \multirow[t]{4}{*}{4.5294} & The group was very creative and was able to work well with the varying personalities. \\
\hline & $\begin{array}{l}\text {--- was self-directed and performed research for her assigned part of the project. She was well prepared } \\
\text { for all group meetings. }\end{array}$ \\
\hline & $\begin{array}{l}\text { Researched and shared information. Helped right slides for presentation. Helped develop ideas for story } \\
\text { background in skits. Communicated appropriately with other members. Formatted and edited skits. }\end{array}$ \\
\hline & Took responsibility for combining everyone's individual research \\
\hline
\end{tabular}

(C) The Internet Journal of Allied Health Sciences and Practice, 2017 


\begin{tabular}{|l|l|}
\hline & $\begin{array}{l}\text { Reported feeling apprehensive in ability to research; however, she did an amazing job and definitely } \\
\text { improved! }\end{array}$ \\
\hline 4.1765 & --- contributed to the overall project and the part that was assigned to her. \\
\cline { 2 - 3 } & --- was able to attend all team meetings and put together her part of the project in a timely manner. \\
\cline { 2 - 3 } & She was very prepared for each meeting. \\
\cline { 2 - 3 } & $\begin{array}{l}\text { We were able to achieve our goal as a group without any inconvenience. We manage the time, and work } \\
\text { with each other's schedules. }\end{array}$ \\
\cline { 2 - 3 } & We accomplished everything we wanted to; she was very reliable and had a lot of helpful ideas \\
\hline 3.8824 & ---- was hardly interactive in our conversations about the project via email and in person \\
\cline { 2 - 3 } & Completed all assigned work \\
\cline { 2 - 3 } & Did research for topic, organized information, created power point slides off of information. \\
\cline { 2 - 3 } & This was a group member and I would not work with again \\
\hline
\end{tabular}

\section{Field Notes}

Students described the team process within the group meetings. Table 16 data indicates that the majority of meetings took place face-to-face. Table 16 shows how each group used the characteristics provided by the form template to structure their meetings. Complete team attendance was the normal make-up. Task delegation was not designated by difficulty or level of professional preparation. Table 17 presents the subjective comments made by the groups describing the nature of the meetings and the level of student performance.

Table 16 Characteristics of Meeting - Process Description

\begin{tabular}{|c|c|c|c|c|c|c|c|c|c|c|c|c|}
\hline Groups & \multicolumn{12}{|c|}{ Meeting Characteristics } \\
\hline Topic Assignments & 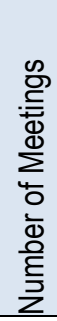 & 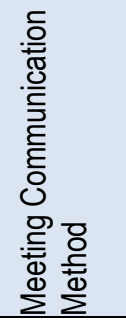 & 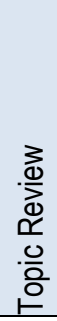 & $\begin{array}{l}\stackrel{0}{\subseteq} \\
\frac{0}{\sigma} \\
\frac{\mathbb{D}}{\omega}\end{array}$ & 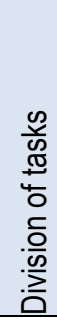 & 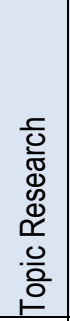 & 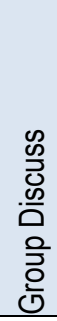 & 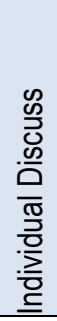 & 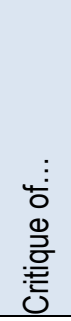 & 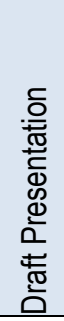 & 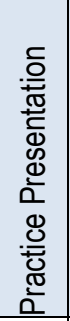 & 总 \\
\hline Professional Behavior & 2 & FF & $\mathrm{x}$ & $\mathrm{x}$ & $\mathrm{x}$ & $\mathrm{x}$ & $\mathrm{x}$ & $\mathrm{x}$ & $\mathrm{x}$ & $\mathrm{x}$ & $\mathrm{x}$ & \\
\hline Ethical Compass & 2 & FF & $\mathrm{x}$ & $\mathrm{x}$ & $\mathrm{x}$ & $\mathrm{x}$ & & & & & & \\
\hline Vision 2020 Statement & 2 & $\mathrm{FF}$ & $\mathrm{x}$ & $\mathrm{x}$ & $\mathrm{x}$ & $\mathrm{x}$ & & & & & & \\
\hline $\begin{array}{l}\text { PT/PTA Representation in APTA Governance } \\
\end{array}$ & 3 & FF & $\mathrm{x}$ & $\mathrm{x}$ & $\mathrm{x}$ & $\mathrm{x}$ & $\mathrm{x}$ & & & $\mathrm{x}$ & & \\
\hline Evidence based practice & 4 & $\mathrm{FF}$ & $x$ & $\mathrm{x}$ & $x$ & $x$ & $\mathrm{x}$ & & & $\mathrm{x}$ & & $\mathrm{x}$ \\
\hline Cultural Competence - Working Culture & 3 & FF & $x$ & $x$ & & & $x$ & & & $x$ & & $x$ \\
\hline Data Collection in patient care & 3 & $\mathrm{FF}(2), \mathrm{E}$ & $x$ & $\mathrm{x}$ & & $\mathrm{x}$ & $x$ & & $\mathrm{x}$ & $\mathrm{x}$ & $\mathrm{x}$ & \\
\hline Health Care Reform & 3 & FF & $\mathrm{x}$ & $\mathrm{x}$ & & $\mathrm{x}$ & $x$ & & & $\mathrm{x}$ & & $x$ \\
\hline Specialization in Physical Therapy Practice & 4 & FF & $\mathrm{x}$ & $\mathrm{x}$ & $\mathrm{x}$ & $\mathrm{x}$ & $\mathrm{x}$ & & $\mathrm{x}$ & $\mathrm{x}$ & & \\
\hline Legal Responsibilities in patient treatment & 3 & $F F(2), E$ & & $\mathrm{x}$ & $x$ & $x$ & $x$ & & $\mathrm{x}$ & & & \\
\hline Clinical Education & 1 & FF & & & $\mathrm{x}$ & & $\mathrm{x}$ & & & & & \\
\hline $\begin{array}{l}\text { Evaluation of performance - Components of best } \\
\text { practice }\end{array}$ & & FF & & & $\mathrm{x}$ & & $\mathrm{x}$ & & & & & \\
\hline
\end{tabular}


Table 17 Description of Meeting Process as Documented on Field Notes

\begin{tabular}{|c|c|}
\hline Groups & Subjective Comments \\
\hline \multirow[t]{5}{*}{ Professional Behaviors } & We discussed the two core documents that we would be comparing. \\
\hline & --- (PTA) and --- (PTA) had brought the two documents that we will be comparing and contrasting. \\
\hline & $\begin{array}{l}\text { Each group member was assigned one task that was comparable between the two groups, and then the } \\
\text { students from the two schools decided to research the topics that were different. }\end{array}$ \\
\hline & To research the topic the APTA website will be used for a great deal of the information. \\
\hline & $\begin{array}{l}\text { Group discussion included creating a patient (mock case) as a motivational hook for our presentation. We } \\
\text { fabricated a patient history that we will use to captivate the attention of our audience and discuss the different } \\
\text { aspects of being a professional }\end{array}$ \\
\hline Ethical Compass & We allocated jobs and researching. Our goal is to put together the full presentation at our next meeting. \\
\hline Vision 2020 Statement & $\begin{array}{l}\text { Reviewed Vision } 2020 \text { and how it was recently changed in the APTA's updated Vision } \\
\text { Reviewed how Vision } 2020 \text { 's } 6 \text { pillars evolved into } 8 \text { new Guiding Principles } \\
\text { Shared information and discussed PT/PTA deadlines, schedules, best mode of communication, and general } \\
\text { timeline to successfully complete project. } \\
\text { Accessed the APTA website's sources via SPT's login to view articles. } \\
\text { Printed and distributed relevant articles and descriptions for entire group. } \\
\text { Division of the tasks included developed outline for an estimated number of slides per Guideline and } \\
\text { description of each topic. } \\
\text { Tasks division identified PTA and PT portions of the presentation to have prepared for our next meeting. } \\
\text { Clarified timeline of Vision statement evolution; start with Vision } 2020 \text { and continue to most recent Vision } \\
\text { statement ( } 8 \text { principle Guidelines). } \\
\text { Talked about Vision } 2020 \\
\text { Shared research that we had done. } \\
\text { Divided up into development and evolution of the PT's and implementation of the statement to the PTA's } \\
\text { Continued topic search included going to the APTA Website and found several additional sources for the } \\
\text { presentation. }\end{array}$ \\
\hline $\begin{array}{l}\text { PT/PTA Representation } \\
\text { in APTA Governance }\end{array}$ & $\begin{array}{l}\text { Took into consideration all the information we found, condensed and prioritized on what we wanted to share } \\
\text { with the class. } \\
\text { Group discussion about plan of action and organization of slides. } \\
\text { Although ---- was not present for the meeting, she contributed a great deal. She sent her slides in advance and } \\
\text { provided her references so the rest of the group could utilize them as needs. }\end{array}$ \\
\hline Evidence based practice & $\begin{array}{l}\text { Went through the project assignment to make sure we were all on the same page as to what the project } \\
\text { entailed } \\
\text { Each shared knowledge of what was expected from each professor. } \\
\text { Divided research fairly. }\end{array}$ \\
\hline $\begin{array}{l}\text { Cultural Competence - } \\
\text { Working Culture }\end{array}$ & $\begin{array}{l}\text { Planned what each was going to do before our next meeting. We all individually researched our own portion, } \\
\text { now we shared Put together a rough draft of slide presentation. }\end{array}$ \\
\hline $\begin{array}{l}\text { Data Collection in } \\
\text { patient care }\end{array}$ & $\begin{array}{l}\text { During our e-mail thread, we established a face-to-face group meeting time. We also discussed our topic and } \\
\text { that we had each found some research on it. The e-mail thread is a great addition to our group because it } \\
\text { allows for easy group communication. } \\
\text { As a group we discussed that at our future meeting when we all meet again face-to-face, we will begin to } \\
\text { create our presentation, while dividing up tasks. This will make for a great presentation, especially the fact that } \\
\text { we will all be together. This was not a long meeting, but it was important to establish a crucial meeting to begin } \\
\text { working on our project. } \\
\text { Made sure everyone understands the topic and the articles that we brought to the meeting. } \\
\text { To share information we discussed what article would best fit our lead article in addition to our other } \\
\text { supplementary sources. } \\
\text { Topic research brought in sources as well as research online for different sources. } \\
\text { The group discussed integration of a skit into our presentation as a motivational hook; discussed what our } \\
\text { topic means to each of us and our different perspectives. } \\
\text { We began working on our Power point. } \\
\text { We discussed our final ideas about the project and added finishing touches on the Power point and others } \\
\text { ideas } \\
\text { The group discussed finalizing presentation and discussing about the order of presenting and order of topics } \\
\text { being presented. } \\
\text { Critiqued/edited our reference page and helped to finalize } \\
\text { Continued presentation into a completed final draft } \\
\text { Did a complete run through of the presentation and made sure it contained all components. }\end{array}$ \\
\hline
\end{tabular}

(c) The Internet Journal of Allied Health Sciences and Practice, 2017 


\begin{tabular}{|c|c|}
\hline Health Care Reform & $\begin{array}{l}\text { Reviewed main points of our topic } \\
\text { Identified common sources that we have all started to look up } \\
\text { To research topic we individually pulled up on-line references as we were meeting and discussing. } \\
\text { Group discussion of plan of attack - decided our next steps from here are to sift through references and } \\
\text { information and use online collaboration (google docs/e-mail) to start to piece together information we find with } \\
\text { availability of live updates. Created "skeleton" of presentation/slides to start filling in information as we continue } \\
\text { to work both individually and collaboratively on project. } \\
\text { Created a Google Doc to share references as we continue to discover them and create a running list } \\
\text { Prior communication using both email and cell phone correspondence to establish a meeting time and location } \\
\text { and establish that we would all bring some preliminary research and general ideas of the topic to our meeting. } \\
\text { Do we need to have citations within the Power point? } \\
\text { We have been doing ongoing research using Google Doc. Whenever one of us finds information, we submit it } \\
\text { into the google doc and add comments to communicate with each other. This has been ongoing since our first } \\
\text { face-to face meeting and allows us to do research at our leisure so that we can work around each other's } \\
\text { schedules. } \\
\text { Topic review of going over our findings } \\
\text { Group discussion about which information should be included } \\
\text { We began to create our Power point presentation. }\end{array}$ \\
\hline $\begin{array}{l}\text { Specialization in } \\
\text { Physical Therapy } \\
\text { Practice }\end{array}$ & $\begin{array}{l}\text { Clarified what the topic meant and exactly what we needed to cover in our presentation. } \\
\text { We shared the ideas we had for how we wanted to go about the presentation. } \\
\text { We divided up the research that needed to be done to make it easier to accomplish the tasks at hand. } \\
\text { We shared the information we found this weekend. } \\
\text { We did more research as a group to clarify some points that were discovered during our individual research } \\
\text { sessions. } \\
\text { Group discussion included that we clarified the helpfulness of a Power point presentation that put together by } \\
\text { the ABPTS and was located on their website. } \\
\text { The group discussed how we want to compose the presentation now that we have the necessary information } \\
\text { to do so. } \\
\text { We also discussed how we were going to find research articles for the topic. The Power point we found had } \\
\text { articles at the end, however, we were not able to locate any that were viewable as a PDF on the internet. } \\
\text { We had to critique what information was necessary to include into the short } 10 \text { minute window of our } \\
\text { presentation and what could be left out. } \\
\text { We also spent time critiquing the handout we had created. } \\
\text { We, as a group, began to comprise a Power point presentation and planned on completing it sometime next } \\
\text { week. } \\
\text { Finalized our information on the PTA certification process. } \\
\text { How the presentation was going to be presented, what we needed to complete, and what interactive activities } \\
\text { we had decided to use for the presentation. } \\
\text { Critique of our handout sheets that were to be given out to the audience. } \\
\text { We went through the whole presentation and finalized our information. }\end{array}$ \\
\hline $\begin{array}{l}\text { Legal Responsibilities in } \\
\text { patient treatment }\end{array}$ & $\begin{array}{l}\text { Inquired about what assignments and deadlines the PTA's had and made sure we could meet these deadlines } \\
\text { with them. } \\
\text { Sent three sources to the group that can be used in the presentation focusing on the legal aspects of the PT } \\
\text { and PTA interaction. } \\
\text { Group discussion about developed ideas on incorporating skits into the presentation and questions to engage } \\
\text { students throughout the presentation. Compiled central list of legal resources to use. } \\
\text { Divided slides/skit development among group members. } \\
\text { Critique of revisions and further development of presentation outline beyond initial proposal }\end{array}$ \\
\hline Clinical Education & $\begin{array}{l}\text { Each person was designated a topic to research in more detail. } \\
\text { The group discussed research, division of topics, scheduling and due dates }\end{array}$ \\
\hline $\begin{array}{l}\text { Evaluation of } \\
\text { performance - } \\
\text { Components of best } \\
\text { practice }\end{array}$ & $\begin{array}{l}\text { Evaluation of performance - components of best practice; most important = EBP, performance evaluation } \\
\text { models, quality of care, communication. } \\
\text { To divide the task each person finds a journal article on their topic and creates a behavioral objective } \\
\text { pertaining to the topic. } \\
\text { The group discussed the timeline of the project: bibliography by --- (e-mail sources to ---) discuss on ---when } \\
\text { next meeting should be. Group discussed our next meeting time. }\end{array}$ \\
\hline
\end{tabular}

\section{DISCUSSION}

The qualitative demographic data describing previous experiences in supervisory or leadership positions explains a possible mindset for the intraprofessional attitude findings (IEPS) in both student groups. Hospitality and sports industry jobs were the two most frequently stated areas of work experience and typically require organization, teamwork, and collaboration. From this prior 
experience, the subjects may have more easily understood the assignments and what was sought after for team success. Where "team life" engenders flexibility of the length of a collaboration or is frequently changing, the identified work experiences would have fostered these characteristics. ${ }^{4}$

The results of the pre/post RIPLS questionnaire indicated that all subjects within this study were ready to participate in the intraprofessional learning process. Within the descriptive statistics considering the mean scores by group, for the Roles and Responsibilities subcategory of the RIPLS, the PT students had a higher level of readiness to engage in intraprofessional learning than the PTA evidenced by higher mean scores throughout.

The most important subcategories to the PT and PTA were Teamwork \& Collaboration and Roles \& Responsibilities. Both groups had a high regard for teamwork and collaboration noted by the high average starting point of pre scores and the significant increase in post scores. This increase in scores indicated that the learning activity within this study was effective. The introduction of professionalism theory and the completion of a joint professionalism project in small groups with mixed teams produced knowledge, skills, and professional attitudinal qualities that are valuable in the inter- and intraprofessional arenas. ${ }^{4}$ The RIPLS validated that the undergraduate PTA and graduate PT students clearly recognizes the professional attitude within themselves and their peer team members. The RIPLS, therefore, provides a means to examine the attitude of the physical therapy professional student coming from the two levels of educational preparation. In the 2012 study conducted by Blue et al that spanned three years of comparison, medical students who engaged in IPE activities "recognized the value and need" of collaboration by a change in attitude..$^{19}$

By definition, the Roles and Responsibilities subcategory indicated that the level of professional education for the particular team member dictated their role and responsibility within any team. ${ }^{38} \mathrm{~A}$ number of studies have shown that in the context of servant leadership, the situational leadership example of the team task advancing the appropriate leader, regardless of discipline, speaks to the non-traditional leader being in place or shared leadership.40-42 Historically, the roles and responsibilities of the doctor was the highest place within the team process. ${ }^{15}$ It can be assumed that the roles and responsibilities of the PT would be held higher than that of the PTA within the survey results. ${ }^{3}$ This study revealed that the PT students valued the assumed lines of responsibility less than the PTA pre/post throughout the entire study noted by no change in score. The PTA initially scored significantly above the PT students valuing the boundaries created by the differences in the level of educational preparation. At the end of the study, the PTA student score lowered significantly indicating that the learning activity blurred the lines of any assumed hierarchy and proved the project to be effective by meeting the stated learning objectives. This created the positive perspective of overlapping responsibilities for the PTA student and revealed that the PT student already possessed the perspective of equal value in team roles and responsibilities. In alignment with Schreiber and Gorezceny, these findings validated that SC PT and STCC PTA students entered this study with high professional regard for each other - an expected attitude or professional characteristic. ${ }^{43}$

The field notes described the results of the group meeting detailing the "blurred lines" of any assumed student roles based upon program degree level. The dominant characteristics present within the meeting process were group topic review, researching of the task, shared information, division of tasks, and group discussion. These areas were determined by frequency count across all groups. The subjective comments received from the students were minimal but are noteworthy as they gave insight to why the dominant meeting characteristics were present. Examples of these comments were "Each group member was assigned one task that was comparable between the two groups, and then the students from the two schools decided to research the topics that were different"; "Shared information and discussed PT/PTA deadlines, schedules, best mode of communication, and general timeline to successfully complete project; "Although ---- was not present for the meeting, she contributed a great deal. She sent her slides in advance and provided her references so the rest of the group could utilize them as needs"; "Went through the project assignment to make sure we were all on the same page as to what the project entailed ...Each shared knowledge of what was expected from each professor...Divided research fairly"

The Health Care Reform group introduced the different ways in which electronic media can be used to create and continue the work of a group but also suggests and reveals a work ethic.

Group discussion of plan of attack - decided our next steps from here are to sift through references and information and use online collaboration (googledocs/e-mail) to start to piece together information we find with availability of live updates. Created [a] "skeleton" of [the] presentation/slides, to start filling in information as we continue to work both individually and collaboratively on project.

(c) The Internet Journal of Allied Health Sciences and Practice, 2017 
The Evaluation of Performance/Best Practice group found an important link in their project work that captures elements of an advance team already in a complex setting; "To divide the task each person finds a journal article on their topic and creates a behavioral objective pertaining to the topic".

The IEPS findings revealed for both the PT and PTA subjects that they had a high regard for each other's roles and place within a team. The subscales of Competence and Autonomy and Perception of Actual Cooperation demonstrated the existence of a high level of congruency. The positive results and supportive subjective comments described by the Performance Evaluation data provided further agreement for the subscales congruency. The high subscale mean scores of the IEPS indicated that the PT and the PTA students were highly invested in cooperating with each other (Table 10). The issue of valuing the competency of other disciplines, trusting input, and performance autonomy was captured by Fernandes et al where a diverse group of allied health professionals had to collaborate in an anatomy class..$^{22}$ In a problem-based learning format, student groups were responsible for managing and presenting medical cases plus conducting the anatomy dissection of the donor. The result was an investment in each other and support and value of each team member's skills as measured by the RILPS, IEP, and qualitative data.

The Performance Evaluation results show that the majority of students were consistent in their responsibilities toward collaboration and synthesis of the learning process and the overall project. The small number of students who scored lowest within the Performance Evaluation process were identified and described by the entire group in terms of their relatedness to team members and their level of cooperation. Table 15 presents examples student descriptions of team member and group interactions related to the Performance Evaluation data. A description of a "consistent" performance by a peer and group is as follows: "Wonderful collaboration! This was a good group to be in. We all were willing to work and help with our project. Even though we did not meet too many times, we stayed in communication by email, and phone, and achieved our goal." A description used to explain the process for lower scores was "We were able to achieve our goal as a group without any inconvenience. We managed the time, and worked with each other's schedules." This level of description distinguished the lacking level of cooperation and gave minimalist terminology to describe the regard that each team member held for one another. The final comment related to the lowest scores stated; "---- was hardly interactive in our conversations about the project via email and in person."

The overarching success from the project can best be described by the faculty observations. The presentations were seamless where the PT and PTA were indistinguishable when standing in front of the entire collaborative group. The assumed role delineation and the graduate educational level of the student did not influence the order of group speakers or introductory/concluding comments. All components of the professionalism projects were completed at the graduate level and the measurable process was described. In terms of the level of presentation, both PT and PTA students had the same level of articulation, attention, complexity of word use, and timed contribution. Leadership depended solely upon the organization of content per the group's choice and construct. In fact, if the students were not known by the particular faculty, an observer would have not been able to identify if the presenter was a PT or PTA student. ${ }^{3}$

The study design had many areas of data collection where qualitative or quantitative preferences of the reader might draw them to different segments rather than valuing the richness of a mixed methods methodology.3.,4 Internal bias generated from faculty evaluation would potentially favor the desire for student success within the course rather than an accomplishment of team skill building. External bias associated with a grade being assigned to the final presentation may have influenced the students' level of participation in the process and overall experience.

\section{Conclusion}

It can be concluded that the entire project gave the student an opportunity to acquire intraprofessional teamwork and collaboration skills and apply them to a learning activity. This activity based research project offered the PT and PTA students an educationallybased preparation opportunity that will be transferred to practice in the healthcare workforce. The expected interprofessional interaction required for successful patient centered teamwork is grounded in intraprofessionalism for physical therapist practice as conceptualized within the model. Is it therefore necessary for intra and interprofessional readiness identification in addition to skill development to be based in a clinical setting or a clinical case? The results from this study indicated that it is possible to provide a rich intraprofessional collaborative opportunity in a non-clinical, professionally based scenario, housed in the classroom setting.

(C) The Internet Journal of Allied Health Sciences and Practice, 2017 


\section{References}

1. Jelley W, Larocque N, Borghese M. Perceptions on the essential competencies for intraprofessional practice. Physiother Can. 2013;65(2):148-51. doi:10.3138/ptc.2012-02. [PMID: 2440376]

2. Jelley W, Larocque N, Patterson S. Intradisciplinary clinical education for physiotherapists and physiotherapist assistants: A pilot study. Physiother Can. 2010;62(1):75-80. doi:10.3138/physio.62.1.75. [PMID: 21197181]

3. Plack MM, Williams S, Miller D, et al. Collaboration Between Physical Therapists and Physical Therapist Assistants. J Phys Ther Educ. 2006;20(1):3-14.

4. King H, Battles J, Baker D, Alonso A. TeamSTEPPS®: Strategies and Tools to Enhance Performance and Patient Safety.; 2008. [PMID: 21249942]

5. MacNaughton K, Chreim S, Bourgeault IL. Role construction and boundaries in interprofessional primary health care teams: a qualitative study. BMC Health Serv Res. 2013;13:486. doi:10.1186/1472-6963-13-486.[PMID: 244267663]

6. $\quad$ Crosier BJ. The PT/PTA Relationship: 4 Things to Know. Perspectives (Montclair). 2011;(February):14-7.

7. Bainbridge L, Nasmith L. Inter and Intra-Professional Collaborative Patient- Centred Care in Postgraduate Medical Education; 2011.

8. Wise HH, Frost JS, Resnik C, Davis BP, Iglarsh ZA. Interprofessional Education: An Exploration in Physical Therapist Education. J Phys Ther Educ. 2015;29(2).

9. Lee R, li P, Pharm D, et al. ACCP WHITE PAPER Interprofessional Education: Principles and Application. American College of Clinical Pharmacy. Pharmacotherapy. 2009;29(3):145-64.

10. Suter E, Arndt J, Arthur N, Parboosingh J, Taylor E, Deutschlander S. Role understanding and effective communication as core competencies for collaborative practice. J Intererprofessional Care. 2009;23:41-51. doi:10.1080/13561820802338579. [PMID: 19142782]

11. Selle KM, Salamon K, Boarman R, Sauer J. Providing interprofessional learning through interdisciplinary collaboration: the role of "modelling". J Interprof Care. 2008;22(January):85-92. doi:10.1080/13561820701714755. [PMID: 18202988]

12. Bellamy J, ed. Professionalism. Prof On-line Course Ser. American Physical Therapy Association. Retrieved at: http://www.apta.org/Professionalism/. Accessed March 6, 2015.

13. Blagg JD. Descriptive Analysis of Level of Implementation in Allied Health Educational ducational Institutions of IOM R Recommended Core Competencies. Internet J Allied Heal Sci Pract. 2009;7(4).

14. Franklin CM, Bernhardt JM, Lopez RP, Long-Middleton ER, Davis S. Interprofessional Teamwork and Collaboration Between Community Health Workers and Healthcare Teams: An Integrative Review. Heal Serv Res Manag Epidemiol. 2015;2(0). doi:10.1177/2333392815573312.

15. Kenaszchuk C, MacMillan K, van Soeren M, Reeves S. Interprofessional simulated learning: short-term associations between simulation and interprofessional collaboration. BMC Med. 2011;9(1):29. doi:10.1186/1741-7015-9-29. [PMID: 21443779]

16. Baldwin JDC Jr.. Some historical notes on interdisciplinary and interprofessional education and practice in health care in the USA. J Interprof Care. 2007;21:23-37.[PMID: 17917941]

17. Munn Z, Tufanaru C, Aromataris E. Recognition of the health assistant as a delegated clinical role and their inclusion in models of care: A systematic review and meta-synthesis of qualitative evidence. Int J Evid Based Healthc. 2013;11(1):3 19. doi:10.1111/j.1744-1609.2012.00304.x. [PMID: 23448325]

18. Barnsteiner JH, Disch JM, Hall L, Mayer D, Moore SM. Promoting interprofessional education. Nurs Outlook. 2007;55:14450. doi:10.1016/j.outlook.2007.03.003.[PMID: 17524802]

19. Blue A V, Zoller JS, Mha JSZ. Promoting interprofessional collaboration through the co-curricular environment. Heal Interprofessional Pract. 2012;1(2).

20. Interprofessional Education Collaborative. Core competencies for interprofessional collaborative practice: Report of an expert panel. Washington DC; 2011.

21. Dubouloz CJ, Savard J, Burnett D, Guitard P. An Interprofessional Rehabilitation University Clinic in Primary Health Care: A Collaborative Learning Model for Physical Therapist Students in a Clinical Placement. J Phys Ther Educ. 2010;24:1924.

22. Fernandes AR, Palombella A, Salfi J, Wainman B. Dissecting through barriers: A mixed-methods study on the effect of interprofessional education in a dissection course with health care professional students. Anat Sci Educ. 2015;316(August):305-16. doi:10.1002/ase.1517. [PMID: 25641912]

23. Titzer JL, Swenty CF, Hoehn WG. An Interprofessional Simulation Promoting Collaboration and Problem Solving among Nursing and Allied Health Professional Students. Clin Simul Nurs. 2012;8. doi:10.1016/j.ecns.2011.01.001.

24. Mostrom E, Ribesky C, Klukos M. Collaboration in Clinical Education: Use of a 2:1 Student Physical Therapist-Student Physical Therapist Assistant Model. Phys Ther Case Reports. 1999;2(2):45-57.

25. Lisa Little Consulting. System Issues, Policies and Practices Affecting Physician Intraprofessionalism; 2011.

26. Colgrove YM, Walton LM, Vanhoose LD. The Effects of Intraprofessional Collaborative Case-Based Learning : A Cohort

(c) The Internet Journal of Allied Health Sciences and Practice, 2017 
Study of Student Physical Therapist and Physical Therapist Assistant Perceptions of the Physical Therapist Assistant 's Role. JRIPE. 2015;5:1-24.

27. Jung $B$, Salvatori $P$, Martin $A$. Intraprofessional fieldwork education: occupational therapy and occupational therapist assistant students learning together. Can J Occup Ther. 2008;75:42-50. doi:10.2182/cjot.06.05x.[PMID: 18323368]

28. Creswell J. A Concise Introduction to Mixed Methods Research. Thousand Oaks, CA: Sage Publications Ltd; 2015.

29. Olson R, Bialocerkowski A. Interprofessional education in allied health: A systematic review. Med Educ. 2014;48:236 46. doi:10.1111/medu.12290.[PMID: 24528458]

30. McFadyen A, Webster V, Strachan K, Figgins E, Brown H, McKechnie J. The Readiness for Interprofessional Learning Scale: a possible more stable sub-scale model for the original version of RIPLS. J Interprof Care. 2005;19(6):595-603. doi:10.1080/13561820500430157.[PMID: 16373215]

31. McFadyen AK, Maclaren WM, Webster VS. The Interdisciplinary Education Perception Scale (IEPS): an alternative remodelled sub-scale structure and its reliability. J Interprof Care. 2007;21(4):433-43. doi:10.1080/13561820701352531.[PMID: 17654160]

32. Wilson WJ, Bennison A, Arnott W, Hughes C, Isles R, Strong J. Perceptions of Assessment Among Undergraduate and Postgraduate Students of Four Health Science Disciplines Study design. Internet J Allied Heal Sci Pract. 2014;12(2):1-8.

33. Professionalism in Physical Therapy: Core Values. Alexandrai VA; American Physical Therapy Association. 2002:1-11.

34. Values Based Behaviors for the Physical Therapist Assistant. Alexandria VA; American Physical Therapy Association. 2011.

35. A Normative Model of Physical Therapist Professional Education: Version 2004. Alexandria VA: American Physical Therapy Association; 2004.

36. A Normative Model of Physical Therapist Assistant Education: Version 2007. Alexandria VA: American Physical Therapy Association; 2007.

37. Cusack T, O'Donoghue G. The introduction of an interprofessional education module: Students' perceptions. Qual Prim Care. 2012;20:231-38. [PMID: 22828679]

38. Parsell G, Bligh J. The development of a questionnaire to assess the readiness of health care students for interprofessional learning (RIPLS). Med Educ. 1999;33(2):95-100. [PMID: 10211258]

39. Luecht RM, Madsen MK, Taugher MP, Petterson BJ. Assessing professional perceptions: design and validation of an Interdisciplinary Education Perception Scale. J Allied Health. 1990;19:181-91.[PMID: 2365636]

40. Neill M, Hayward KS, Peterson T. Students' perceptions of the interprofessional team in practice through the application of servant leadership principles. J Interprof Care. 2007;21(4):425-32. doi:10.1080/13561820701443512. [PMID: 17654159]

41. Martin J, Ummenhofer W, Manser T, Spirig R. Interprofessional collaboration among nurses and physicians: Making a difference in patient outcome. Swiss Med Wkly. 2010;(May). doi:10.4414/smw.2010.13062. [PMID: 20458647]

42. Farrell MP, Schmitt MH, Heinemann GD. Informal roles and the stages of interdisciplinary team development. J Interprof Care. 2001;15:281 -95. doi:10.1080/13561820120068980. [PMID: 11705236]

43. Schreiber J, Goreczeny A. The effects of a single event interprofessional education (IPE) experience on occupational therapy students' attitudes toward IPE. Internet J Allied Heal Sci Pract. 2014;12(1):1-8.

44. Frels RK, Onwuegbuzie AJ. Administering quantitative instruments with qualitative interviews: A mixed research approach. Journal of Counseling and Development. 2013;91(April):184-94. doi:10.1002/j.1556-6676.2013.00085.x. 